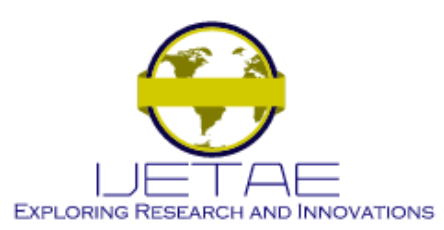

International Journal of Emerging Technology and Advanced Engineering Website: www.ijetae.com (ISSN 2250-2459, ISO 9001:2008 Certified Journal, Volume 4, Issue 4, April 2014) \title{
Design and Analysis of Maglev Vertical Axis Wind Turbine
}

\author{
B. Bittumon ${ }^{1}$, Amith Raju ${ }^{2}$, Harish Abraham Mammen ${ }^{3}$, Abhy Thamby ${ }^{4}$, Aby K Abraham ${ }^{5}$ \\ ${ }^{1,2,3,4}$ Graduate Scholar's in Department of Mechanical Engineering, Gurudeva Institute of Science and Technology. \\ ${ }^{5}$ Professor in Mechanical Engineering Gurudeva Institute Of Science And Technology, Kottayam, Kerala, India
}

\begin{abstract}
A combined savonius and darrieus vertical axis wind turbine would have many advantages over an individual savonius or darrieus rotor. A savonius produces high torque which would be useful in self-starting and darrieus rotor having a high tip speed ratio useful for electrical generation. However research on combined savonius and darrieus rotors is very scarce. This developed a two bucket savonius rotor and placed it on the central shaft of a traditional darrieus. Though the tip speed ratio is a still a little low for use as an electrical generator, the research demonstrated a simple way to enable a darrieus VAWT to be self-starting and achieve higher efficiencies. Historically VAWTs cost more to operate and maintain than HAWTs Finally, traditional Darrieus rotors are not self-starting under most of wind conditions and manufacture of their blades is a challenge because of the complex shape which adds expense to the turbine. However, evidence shows that a Darrieus turbine using fixed geometry symmetrical airfoils can self-start in the field during atmospheric gusting it was suggested that using a Darrieus blade together with a Savonius blade has better performance than using them individually according to self-start ability and efficiency of the turbine. Using a counter rotating wind turbine with a freely rotating generator can produce higher amounts of power than common wind generators.
\end{abstract}

Keywords - VAWTs, HAWTs, Savonius, Darrieus, Maglev Technology

\section{INTRODUCTION}

Now a day, we will ultimately need to search for renewable or virtually inexhaustible energy for the human development to continue. Renewable energy [1] is generally electricity supplied from sources, such as wind power, solar power, geothermal energy, hydropower and various forms of biomass. The popularity of renewable energy has experienced a significant upsurge in recent times due to the exhaustion of conventional power generation methods. The exploration of renewable energy is the only approach to reduce our dependence on fossil fuels. Among the renewable energy sources Wind Energy is one of the fastest growing energy sources which is growing at the rate of $30 \%$ annual graph

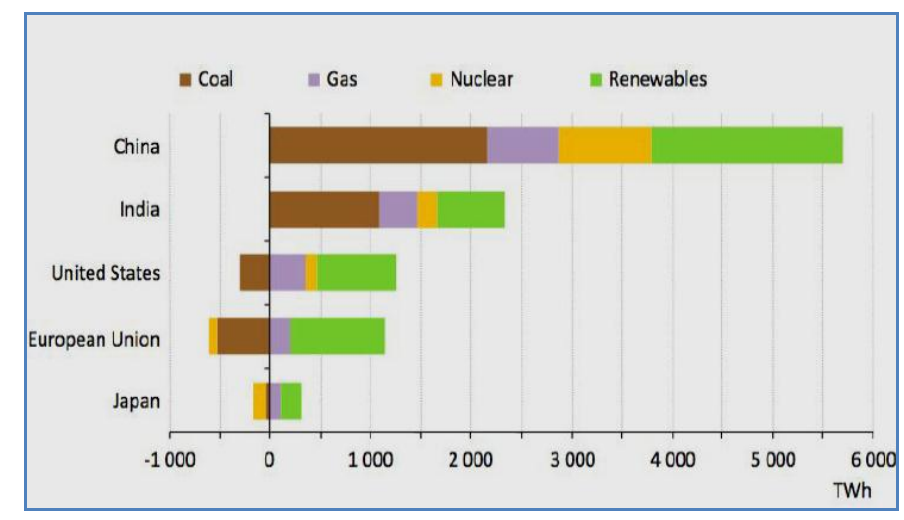

Figure I. Power Generation 2010 -2013

The wind speeds in most of Asian zone is much lower than $7 \mathrm{~m} / \mathrm{s}$, especially in the cities, but the mechanical frictional resistance of existing wind turbines is too big, usually it can't start up when the wind speed is not big enough. This project introduces structure and principle of the proposed magnetic levitation wind turbine for better utilization of wind energy. Maglev Wind turbine has the features of no mechanical contact, no friction [2] etc. minimizing the damping in the magnetic levitation wind turbine, which enables the wind turbine start up with low speed wind and work with breeze.

The Maglev [5] wind turbine, which was first unveiled at the Wind Power Asia exhibition in Beijing, is expected take wind power technology to the next level with magnetic levitation. Magnetic Levitation (Maglev) into turbine system in order to increases the efficiency. If the efficiency of a wind turbine is increased, then more power can be generated thus decreasing the need for expensive power generators that cause pollution. Since one of the main complaints about wind turbines is the sound they produce, this is a huge advantage over other turbine designs.

\section{BASIC DESIGN}

The effective functioning of a wind turbine is dictated by the wind availability in an area and if the amount of power it has is sufficient enough to keep the blades in constant rotation. 


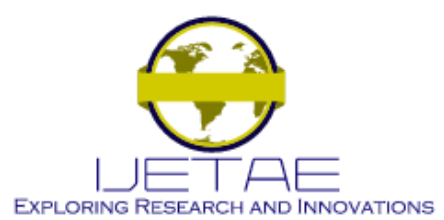

\section{International Journal of Emerging Technology and Advanced Engineering Website: www.ijetae.com (ISSN 2250-2459, ISO 9001:2008 Certified Journal, Volume 4, Issue 4, April 2014)}

The wind power increases as a function of the cube of the velocity of the wind and this power is calculable with respect to the area in which the wind is present as well as the wind velocity.

Kinetic energy $[11]($ K.E $)=1 / 2 \mathrm{mv}^{2}$

Amount of Air passing is given by

$$
\mathrm{m}=\rho \mathrm{AV}
$$

Substituting this value of the mass in expression of K.E.

$$
\text { K.E }=\quad 1 / 2 \rho \mathrm{Av}^{3} \text { watts }
$$

To convert power to kilo watt a non-dimensional proportionality constant $\mathrm{k}$ is introduced where, $\mathrm{k}=2.14 \mathrm{X}$ $10^{-3}$

Therefore

$$
\text { Power in } \mathrm{KW}(\mathrm{P})=2.14 \rho \mathrm{Av}^{\mathrm{a}} \times 10^{-\mathrm{a}} \ldots
$$

Where

$\mathrm{m}=$ mass of air traversing

Air Density $(\rho)=1.2 \mathrm{~kg} / \mathrm{m} 3$

Area $(\mathrm{A})=$ area swept by the blades of the turbine

Velocity $(\mathrm{V})=$ wind speed

With equation above, the power being generated can be calculated, however one should note that it is not possible to convert all the power of the wind into power. The turbine absorbs the wind energy with their individual blade will move slower that the wind velocity. The different speed generates a drag force to drive the blades. The drag force $F W$ acting on one blade is calculated as

$$
F w=C d 2 A\left(\frac{U w-U b}{2}\right)
$$

Where

A is swept area of the blade

$\rho$ is air density (about $1.225 \mathrm{~kg} / \mathrm{m} 3$ at sea level)

UW is wind speed

Cd is the drag coefficient (1.9 for rectangular form)

$U b$ is the speed on the blade surface.

\section{MATERIALS WIND TURBINES}

A wide range of materials are used in wind turbines. There are substantial differences between small and large machines and there are projected changes in designs that will accommodate the introduction of new material technologies and manufacturing methods.
To arrive at a total, the material ${ }^{7}$ usage is weighted by the estimated market share of the various manufacturers and machines types.

TABLE I

Property VAlues of Al 6061-T6

\begin{tabular}{|l|l|}
\hline \multicolumn{1}{|c|}{ Property } & \multicolumn{1}{c|}{ Value } \\
\hline Density & $2712.000 \mathrm{~kg} / \mathrm{m}^{\wedge} 3$ \\
\hline Thermal Conductivity & $0.180 \mathrm{~kW} / \mathrm{m}-\mathrm{C}$ \\
\hline Specific Heat & $920.000 \mathrm{~J} / \mathrm{kg}-\mathrm{C}$ \\
\hline Modulus of Elasticity & $68947.570 \mathrm{MegaPa}$ \\
\hline Poisson's Ratio & 0.330 \\
\hline Yield Stress & $275.790 \mathrm{MegaPa}$ \\
\hline Ultimate Stress & $310.264 \mathrm{MegaPa}$ \\
\hline
\end{tabular}

Physically, chemically and mechanically aluminum is a metal like steel, brass, copper, zinc, lead or titanium. Aluminum is a very light metal with a specific weight of $2.7 \mathrm{~g} / \mathrm{cm}^{2}$, about a third that of steel. Its strength can be adapted to the application required by modifying the composition of its alloys. Aluminium naturally generates a protective oxide coating and is highly corrosion resistant. Aluminum is a good reflector of visible light as well as heat, and that together with its low weight makes it an ideal material for reflectors in, for example, light fittings or rescue blankets.

Aluminum is strong with a tensile strength of 70 to 700 MP depending on the alloy and manufacturing process [3]. Extrusions of the right alloy and design are as strong as structural steel. This means that the moment of inertia has to be three times as great for an aluminum extrusion to achieve the same deflection as a steel profile.

\section{MAGNet SELECTION}

Some factors need to be assessed in choosing the permanent magnet selection that would be best to implement the maglev portion of the design. Understanding the characteristics of magnet materials and the different assortment of sizes, shapes and materials is critical. There are four classes of commercialized magnets used today which are based on their material composition each having their own magnetic properties. 


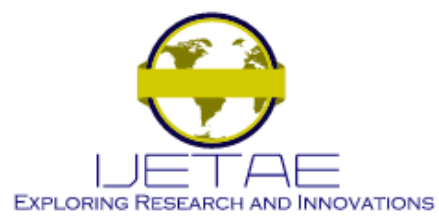

\section{International Journal of Emerging Technology and Advanced Engineering Website: www.ijetae.com (ISSN 2250-2459, ISO 9001:2008 Certified Journal, Volume 4, Issue 4, April 2014)}

The four different classes are Alnico, Ceramic, Samarium Cobalt and Boron neodymium Iron [8]also known Nd-Fe-B. Nd-Fe-B is the most recent addition to this commercial list of materials and at room temperature exhibits the highest properties of all of the magnetic materials.

All of the following information is supported by reference and explains the importance of the $\mathrm{B}-\mathrm{H}$ curve [4]corresponding to magnet design. The hysteresis loops also known as the B-H curve, where B is the flux density and $\mathrm{H}$ the magnetizing force, is the foundation to magnet design and can be seen in Figure 3. Each type of material has its own B-H characteristic which describes the cycling of the magnet in a closed circuit as it is brought to saturation, demagnetized, saturated in the opposite direction, and then demagnetized again under the influence of an external magnetic field. Of the four quadrants that the hysteresis loop passes through on the B-H graph, the most important is the second. This quadrant commonly known as the demagnetization curve, will give the operating point of a permanent magnet at a given air gap. In the case of maglev for the wind turbine, the air gap corresponds to the space in between the two opposing magnets and should stay moderately constant as long as the wind [5] is not too violent. If the air gaps where to change, the operating point of the magnets on the B-H curve will change respectively.

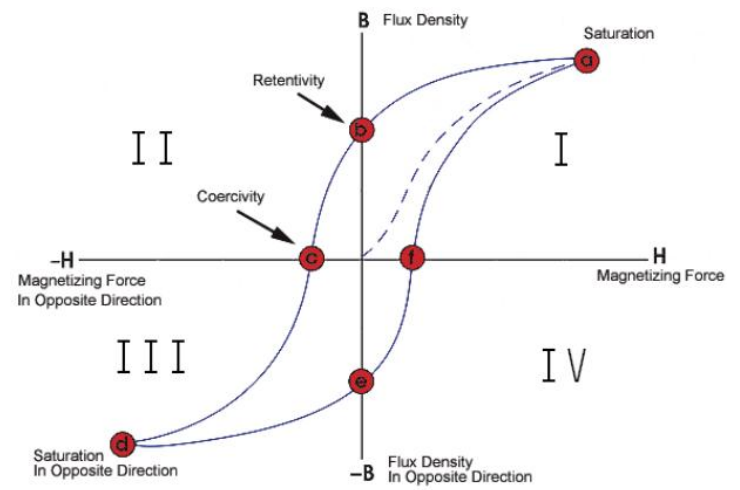

Figure II. General Hysteresis Loop

The most important points of the hysteresis loop are when it intersects with the B-H. The point where the curve intersects the B axis in the second quadrant is known as the magnets retentively, which is the point where a material will stay magnetized after an external magnetizing field is removed.
It seems that levitation would be most effective directly on the central axis line where, under an evenly distributed load, the wind turbine center of mass will be found as seen in Figure 4. This figure shows a basic rendition of how the maglev will be integrated into the design. If the magnets where ring shaped then they could easily be slid tandem down the shaft with the like poles [9] facing toward each other. This would enable the repelling force required to support the weight and force of the wind turbine and minimize the amount of magnets needed to complete the concept.

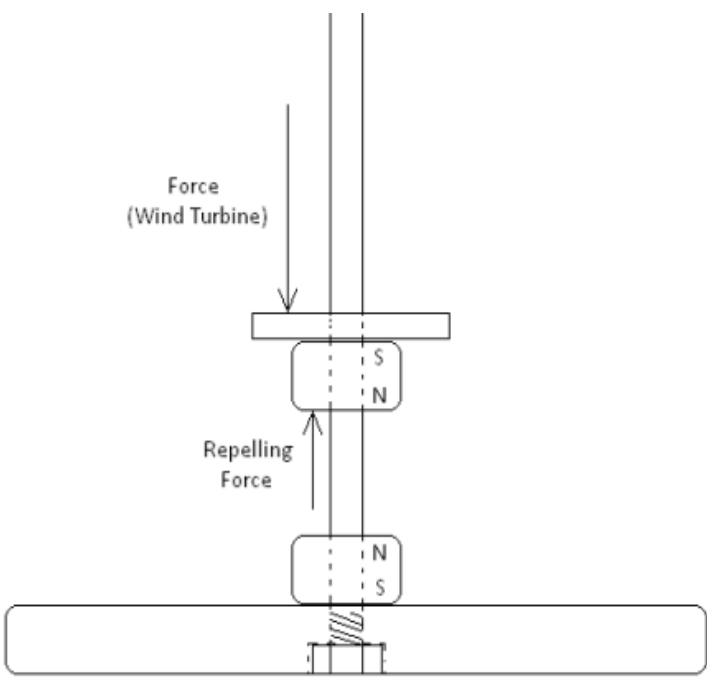

Figure III.-Basic Magnet Placement

The permanent magnets that were chosen for this application were the NX8CC-N42 magnets from K\&J Magnetics. These are $\mathrm{Nd}-\mathrm{Fe}-\mathrm{B}$ ring shaped permanent magnets that are nickel plated to strengthen and protect the magnet itself. The dimensions for the magnets are reasonable with outside diameter of 1.5 inches, inside diameter of 0.75 inches and height of 0.75 inches.

\section{ANALYSIS}

Solid Edge is a computer-aided design (CAD) system for mechanical assembly, part modeling, and drawing production. Developed by STREAM Technology [6] with an interface that ensures maximized user productivity and return on investment. Solid Edge has separate environments for creating parts, constructing assemblies, and producing drawings. Each environment is selfcontained. 


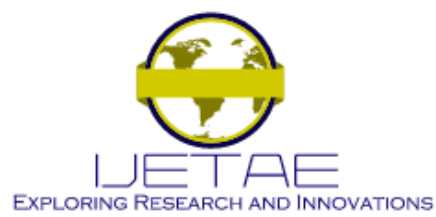

International Journal of Emerging Technology and Advanced Engineering

Website: www.ijetae.com (ISSN 2250-2459, ISO 9001:2008 Certified Journal, Volume 4, Issue 4, April 2014)

TABLE II

LOAD DESCRIPTIONS FOR DARRIEUS BLADES

\begin{tabular}{|l|l|l|l|l|}
\hline $\begin{array}{l}\text { Load } \\
\text { Type }\end{array}$ & $\begin{array}{l}\text { Load } \\
\text { Valu } \\
\text { e }\end{array}$ & $\begin{array}{l}\text { Load } \\
\text { Distributio } \\
\text { n }\end{array}$ & Load & $\begin{array}{l}\text { Load } \\
\text { Directio } \\
\text { n }\end{array}$ \\
\hline $\begin{array}{l}\text { Pressu } \\
\mathrm{r}\end{array}$ & $\begin{array}{l}0.03 \\
\mathrm{kPa}\end{array}$ & Equal & $\begin{array}{l}\text { Compressio } \\
\mathrm{n}\end{array}$ & $\begin{array}{l}\text { Normal } \\
\text { to face }\end{array}$ \\
\hline
\end{tabular}

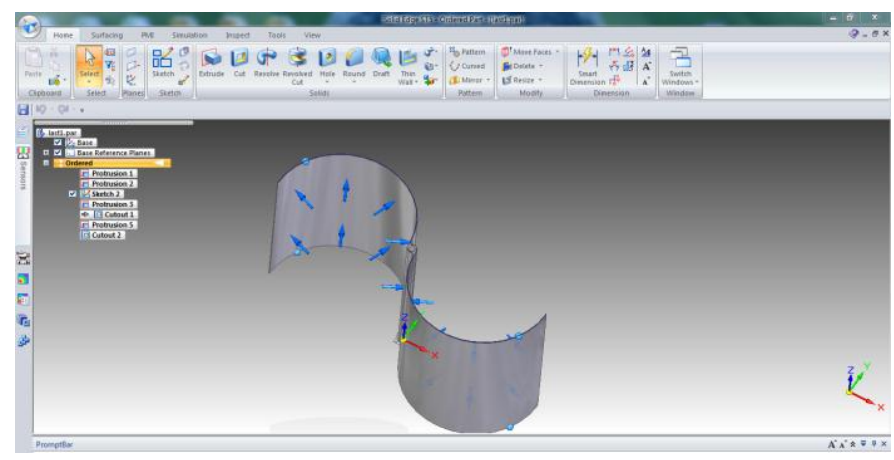

Figure IV. Design of Darrieus blades

For example, all the commands you need to create a drawing are in the Draft environment. The environments are tightly integrated, making it easy to move among them to complete your designs. Solid Edge with synchronous technology combines the speed and flexibility of direct modeling with precise control of dimension-driven design to provide the fastest, most flexible design experience possible.

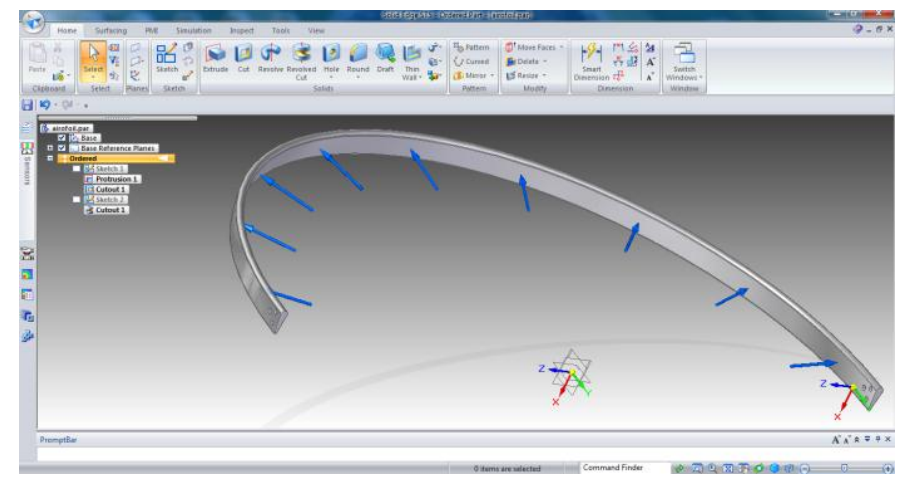

Figure IV.Design of Savonius blades

With superior part and assembly modeling, drafting, transparent data management and built-in finite element analysis, Solid Edge is a core component of the Velocity Series portfolio that eases the growing complexity of product design.
Solid Edge modeling and assembly tools enable to easily develop a full range of products, from single parts to assemblies containing thousands of components.

TABLE III

LOAD DESCRIPTIONS FOR SHAFT

\begin{tabular}{|l|l|l|l|}
\hline $\begin{array}{l}\text { Load } \\
\text { Type }\end{array}$ & Load Value & $\begin{array}{l}\text { Load } \\
\text { Distribu } \\
\text { tion }\end{array}$ & $\begin{array}{l}\text { Load } \\
\text { Direction } \\
\text { Option }\end{array}$ \\
\hline Gravity & $981 \mathrm{~cm} / \mathrm{s}^{\wedge} 2$ & $\begin{array}{l}\text { Along a } \\
\text { vector }\end{array}$ \\
\hline Torque & $71.7 \mathrm{~N}-\mathrm{m}$ & $\begin{array}{l}\text { Per } \\
\text { Entity }\end{array}$ & $\begin{array}{l}\text { Radially } \\
\text { outward }\end{array}$ \\
\hline $\begin{array}{l}\text { Centrifuga } \\
1\end{array}$ & $\begin{array}{l}\text { Angular } \\
3 \mathrm{deg} / \mathrm{s}^{\wedge} 2\end{array}$ & $\begin{array}{l}\text { Normal to } \\
\text { face }\end{array}$ \\
\hline Bearing & $\begin{array}{l}6.5 \mathrm{e}+003 \\
180.00^{\circ}\end{array}$ & $\begin{array}{l}\text { Per } \\
\text { Entity }\end{array}$ \\
\hline
\end{tabular}

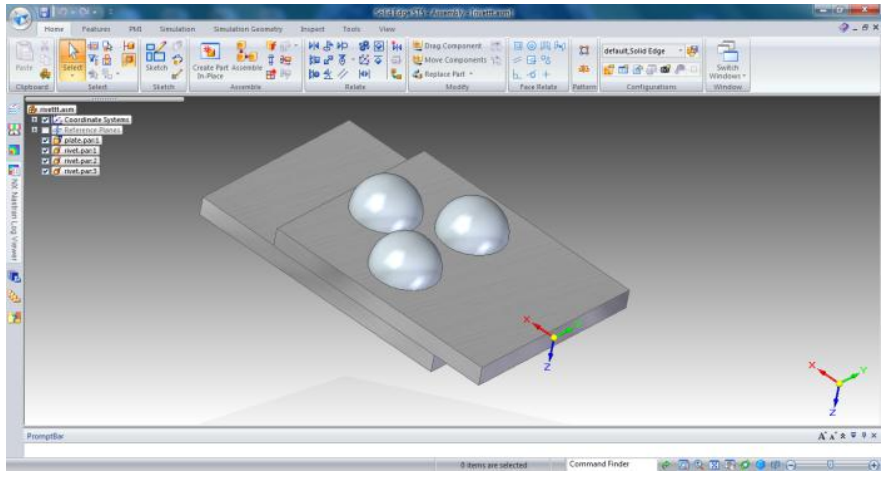

Figure IV. Design of lozents joint

TABLE IV

LOAD DESCRIPTIONS FOR RIVETED JOINT

\begin{tabular}{|l|l|l|l|l|}
\hline $\begin{array}{l}\text { Load } \\
\text { Type }\end{array}$ & $\begin{array}{l}\text { Load } \\
\text { Value }\end{array}$ & $\begin{array}{l}\text { Load } \\
\text { Distribution }\end{array}$ & $\begin{array}{l}\text { Load } \\
\text { Direction }\end{array}$ & $\begin{array}{l}\text { Load } \\
\text { Direction }\end{array}$ \\
\hline Force & $\begin{array}{l}3 \mathrm{e}+004 \\
\mathrm{mN}\end{array}$ & Per Entity & $\begin{array}{l}(0.00,0.00,- \\
1.00)\end{array}$ & $\begin{array}{l}\text { Along a } \\
\text { vector }\end{array}$ \\
\hline
\end{tabular}




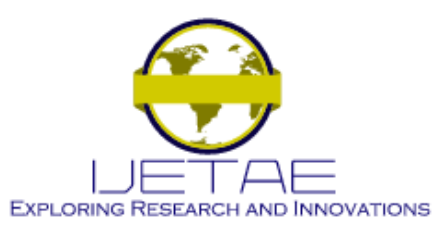

International Journal of Emerging Technology and Advanced Engineering

Website: www.ijetae.com (ISSN 2250-2459, ISO 9001:2008 Certified Journal, Volume 4, Issue 4, April 2014)

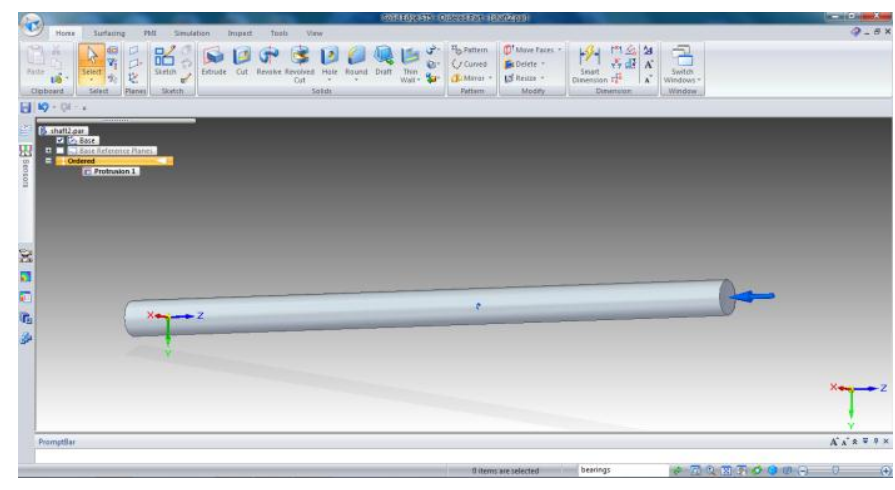

Figure VI. Design of shaft

\section{RESULT}

The following diagrams shows the analysis result obtained by NX Trogen software of solid edge and the observations results shows they are within the range of operation.

TABLE V

LOAD DESCRIPTIONS FOR SAVONIUS BLADES

\begin{tabular}{|c|c|c|c|c|}
\hline \multicolumn{5}{|c|}{ Result component: Von Mises } \\
\hline Extent & Value & $\mathrm{X} \mathrm{mm}$ & $\begin{array}{l}\mathbf{Y} \\
\mathbf{m m}\end{array}$ & $\mathrm{Z} \mathbf{~ m m}$ \\
\hline Minimum & $\begin{array}{l}0.00165 \\
\text { MegaPa }\end{array}$ & 33.791 & $\begin{array}{l}21.40 \\
5\end{array}$ & $\begin{array}{l}623.82 \\
7\end{array}$ \\
\hline Maximum & $\begin{array}{l}0.0747 \\
\text { MegaPa }\end{array}$ & $\begin{array}{l}- \\
1246.000\end{array}$ & 0.000 & 2.084 \\
\hline
\end{tabular}

Figure 13 Analysis results of Savonius blades

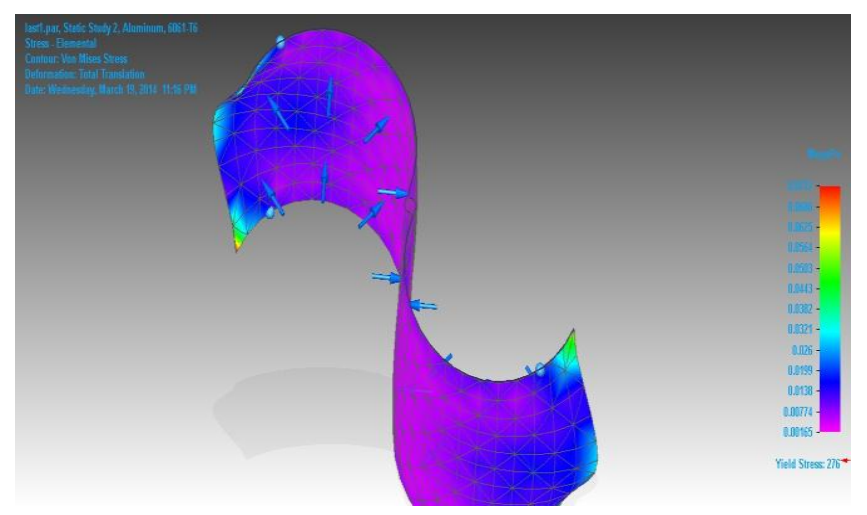

Figure VII. Analysis of Savonius blades
TABLE VI

ANALYSIS RESUlt OF DARRIEUs blades

\begin{tabular}{|c|c|c|c|c|}
\hline \multicolumn{5}{|c|}{ Result component: Von Mises } \\
\hline Extent & Value & $\mathbf{X}$ & $\mathbf{Y}$ & $\mathbf{Z}$ \\
\hline Minimum & $\begin{array}{l}0.883 \\
\text { MegaP } \\
\mathrm{a}\end{array}$ & $\begin{array}{l}15.91 \\
0 \mathrm{~mm}\end{array}$ & $\begin{array}{l}- \\
15.91 \\
0 \mathrm{~mm}\end{array}$ & $\begin{array}{l}459.59 \\
5 \mathrm{~mm}\end{array}$ \\
\hline $\begin{array}{l}\text { Maximu } \\
\mathrm{m}\end{array}$ & $\begin{array}{l}12.8 \\
\text { MegaP } \\
\text { a }\end{array}$ & $\begin{array}{l}- \\
15.91 \\
0 \mathrm{~mm}\end{array}$ & $\begin{array}{l}- \\
15.91 \\
0 \mathrm{~mm}\end{array}$ & $\begin{array}{l}743.26 \\
6 \mathrm{~mm}\end{array}$ \\
\hline
\end{tabular}

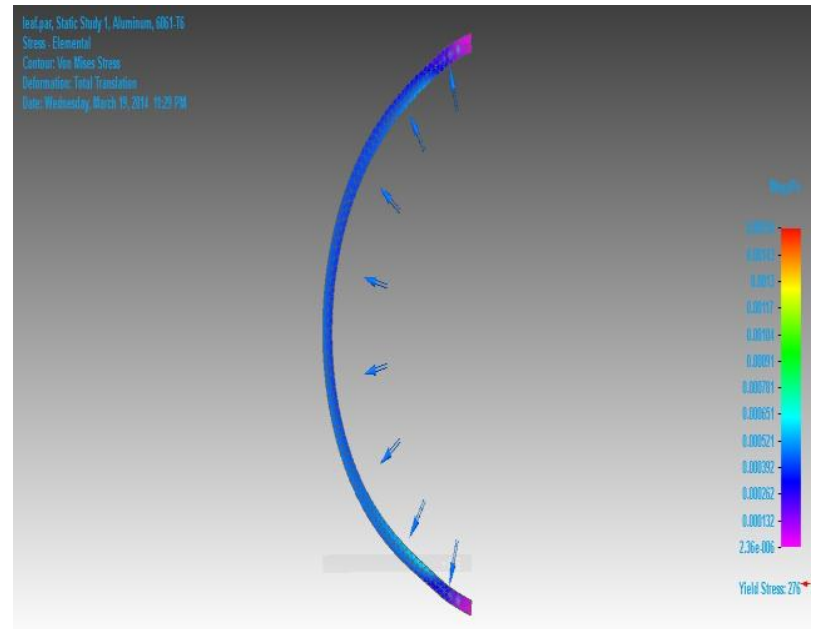

Figure VIII. Analysis of Darrieus s blades

TABLE VII

ANALYSIS RESULT OF RIVETED JOINT

\begin{tabular}{|c|c|c|c|c|}
\hline \multicolumn{5}{|c|}{ Result component: Von Mises } \\
\hline Extent & Value & $\mathrm{X} \mathrm{mm}$ & $\begin{array}{l}\mathbf{Y} \\
\mathbf{m m}\end{array}$ & $\mathrm{Z} \mathbf{~ m m}$ \\
\hline $\begin{array}{l}\text { Minimu } \\
\mathrm{m}\end{array}$ & $\begin{array}{l}1.16 \mathrm{e}-008 \\
\mathrm{MegaPa}\end{array}$ & -8.333 & $\begin{array}{l}- \\
5.000\end{array}$ & $\begin{array}{l}118.80 \\
3\end{array}$ \\
\hline $\begin{array}{l}\text { Maximu } \\
\mathrm{m}\end{array}$ & 0.0489 MegaPa & - & 5.000 & 28.078 \\
\hline
\end{tabular}




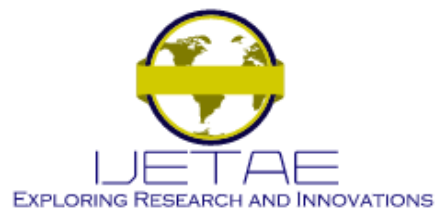

International Journal of Emerging Technology and Advanced Engineering

Website: www.ijetae.com (ISSN 2250-2459, ISO 9001:2008 Certified Journal, Volume 4, Issue 4, April 2014)

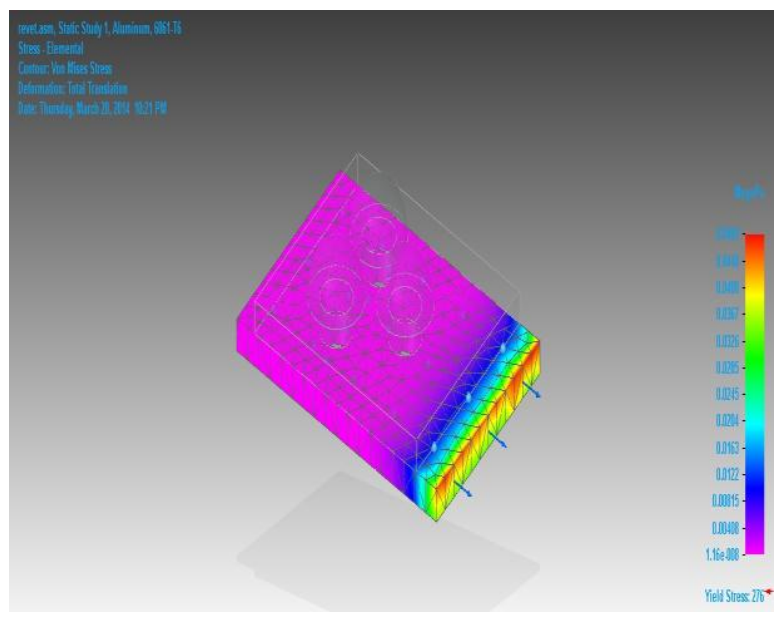

Figure IX. Analysis of Riveted Joint

TABLE VIII

ANALYSIS RESULT OF SHAFT

\begin{tabular}{|l|l|l|l|l|}
\hline \multicolumn{2}{|l|}{ Result component: Von Mises } \\
\hline Extent & Value & X mm & Y mm & $\mathbf{Z ~ m m}$ \\
\hline Minimum & $\begin{array}{l}0.883 \\
\text { MegaPa }\end{array}$ & 15.910 & -15.910 & 459.595 \\
\hline Maximum & $\begin{array}{l}12.8 \\
\text { MegaPa }\end{array}$ & -15.910 & -15.910 & 743.266 \\
\hline
\end{tabular}

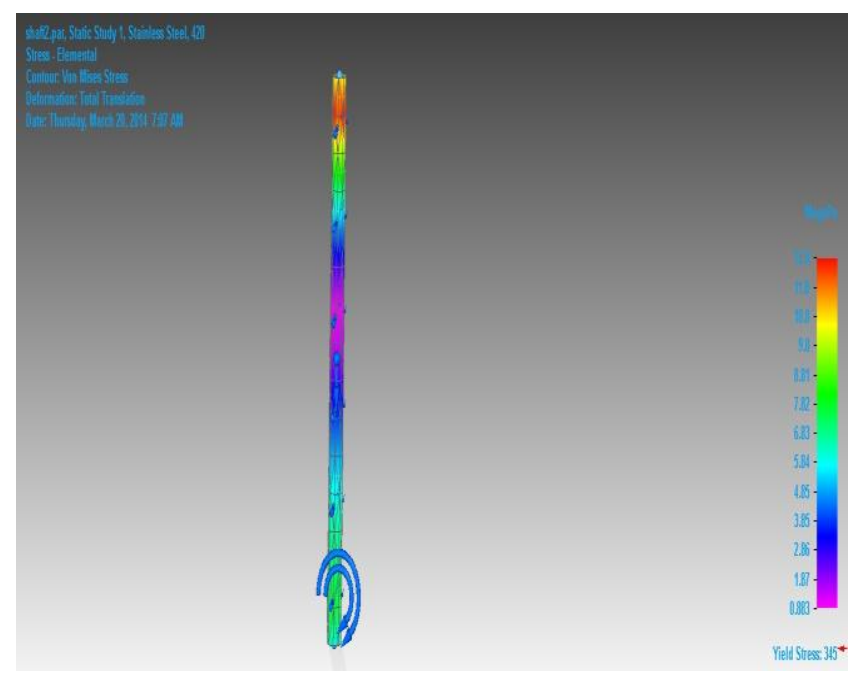

Figure X. Analysis of shaft

\section{CONCLUSION}

Over all, the magnetically levitated vertical axis wind turbine was a success. The rotors that were designed harnessed enough air to rotate the stator at low and high wind speeds while .Keeping the center of mass closer to the base yielding stability. The wind turbine rotors and Stator levitated properly using permanent magnets which allowed for a smooth rotation with negligible friction. At moderate wind speeds the power output of the generator satisfied the specifications needed to supply the LED load. Lastly the SEPIC circuit operated efficiently and to the specifications that were slated at the beginning of the circuit design. After testing the project as an overall system we found that it functioned properly but there feel limited the amount of power it could output.

\section{REFERENCES}

[1] Bernhoff, H., Eriksson, S., \& Leijon, M (2006). Evaluation of different turbine concepts for wind power. Renewable \& Sustainable Energy Reviews, 12(5), 1419-1434.

[2] Biswas, A., Gupta, R. \& Sharma, K. K., (2008). Comparative study of a three-bucket Savonius rotor with a combined three-bucket Savonius-three-bladed Darrieus rotor. Renewable Energy, 33, 1974-1981.

[3] Cheremisinoff, N. P. (1978). Fundamentals of wind energy. Ann Arbor, MI: Ann Arbor Science. Cooper, P., \& Kennedy, O. (2005). Development and analysis of a novel vertical axis wind turbine.

[4] Craig, G. (1985).Introduction to Aerodynamics. Anderson, IN: Regenerative Press. Da Rosa, A.D. (2009). Fundamentals of Renewable Energy Processes, 2nd Edition. New York, NY: Elsevier

[5] Datta, P. K., Leung, P. S., \& Roynarin W., (2002). The performances of a vertical Darrieus machine with modern high lift airfoils. Proceedings from IMAREST conference MAREC 2002, Newcastle,

[6] UK. Dom, J. (March 4, 2008). Global wind power capacity reaches 100, 000 megawatts. Retrieved September 14, 2008 from http://www.earthpolicy.org /Indicators /Wind f2008.htm Brown, L. D., Hua, H., and Gao, C. 2003. A widget framework for augmented interaction in SCAPE.

[7] Fartaj, A., Islam, M., \& Ting, D.S.K. (2006). Aerodynamic models for Darrieus-type straight-bladed vertical axis wind turbines Renewable \& Sustainable Energy Reviews, 12(4), 1087-11 08.

[8] Gipe, P. (2004). Wind power. White River Junction, VT: Chelsea Green Publishing Co. Islam, M., Ting, D., \& Fartaj, A. (2007). Desirable airfoil features for smaller-capacitystraight-bladed vawt. Wind Engineering, 31(3), 165-196.Islam, M., Ting, D., \& Fartaj, A. (2007). Design of a special-purpose airfoil for smaller capacity straight 